\title{
PENGARUH KUALITAS SUMBER DAYA MANUSIA DAN MOTIVASI KERJA TERHADAP KINERJA PEGAWAI DAN DAMPAKNYA TERHADAP EFEKTIFITAS ORGANISASI PADA BAGIAN KESEJAHTERAAN RAKYAT SEKRETARIAT DAERAH KABUPATEN KARAWANG
}

\author{
INFLUENCE OFTHE QUALITY OFHUMAN \\ RESOURCESANDMOTIVATION TOWORKTHE PERFORMANCE \\ OFEMPLOYEESAND THEIMPACT ONTHE EFFECTIVENESS OFTHE \\ ORGANIZATIONOFTHEPEOPLE'S WELFAREREGIONALSECRETARIAT \\ DISTRICTKARAWANG
}

\author{
Yeni Maryani \\ yenimaryani1579@gmail.com
}

\begin{abstract}
Influence of the quality of Human Resource and motivation to work the Performance of employees and the Impact on the effectiveness of the organization of the people's welfare regional secretariat District Karawang. the Purpose of this study to obtain empirical evidence and found the clarity of the phenomenon and conclusions about the influence of Quality of Human Resources and Work Motivation Against Employee Performance and Its Impact on Organizational Effectiveness in the Public Welfare Section Karawang District Secretariat. Basedon data analysis, it indicates regression equation $\mathbf{Z}=\mathbf{0 , 3 5} \mathrm{X1}+$ $0,62 X 2+0,889 Y+\varepsilon 1+\varepsilon 2$. The result show that the quality of human resource, motivation to work and the performance of employees perform positive and significant effect on effectiveness of the organization. Determination test indicates that the value of adjusted $R$ square is 0,79 which means that $79 \%$ quality of human resource and motivation to work. Meanwhile, $21,1 \%$ is affected by other variables which are not investigated in this research

Keywords : Quality of Human Resources, Motivation, employee performance and

organizational effectiveness
\end{abstract}

\section{Pendahuluan}

Suatu organisasi didirikan sebagai suatu wadah untuk mencapai tujuan. Organisasi tersebut harus mengelola berbagai rangkaian kegiatan yang diarahkan menuju tercapainya tujuan organisasi. Organisasi yang berhasil dapat diukur dengan melihat pada sejauhmana organisasi tersebut dapat mencapai tujuan yang sudah ditetapkan. Hal ini sejalan dengan pendapat Etzionidalam Lubis dan Huseini,(1999 : 54), "Efektivitas organisasi dapat dinyatakan sebagai tingkat 
keberhasilan organisasi dalam usaha mencapai tujuan atau sasaran”. Berdasarkan pendapat ini efektivitas merupakan suatu konsep yang sangat penting karena mampu memberikan gambaran mengenai keberhasilan atau kegagalan organisasi dalam mencapai tujuannya.Efektivitas organisasi dapat dilihat sejauh mana organisasi melaksanakan seluruh tugas pokoknya atau mencapai semua sasaran.Keefektivitasan dapat memberikan pengertian ganda yaitu efektivitas organisasi dan efektivitas sumber daya yang ada dalam suatu organisasi. Demikian pula konsekuensi pengukurannya juga akan bervariasi atau bermacammacam persepsi, dan hasilnya juga akan berbeda. (Ravianto, 2000:113)

Semangat otonomi daerah sebagaimana yang diamanatkan oleh Undang-undang nomor 22 tahun 1999 diperbaharui dengan Undang-undang nomor 32 tahun 2004 tentang Pemerintah Daerah, dan Undang-undang nomor 25 tahun 1999 tentang Perimbangan Keuangan antara Pusat dan daerah, maka perlunya pengendalian potensi daerah yang sesuai dengan visi dan misi daerah tersebut dalam mensejahterakan masyarakat. Salah satu tuntunan dalam perubahan sistem penyelenggaraan Pemerintah Daerah adalah penyelenggaraan prinsipprinsip kepemerintahan yang baik (good governance) yang meliputi konsensus akuntabilitas, partisipasi, efektif, dan efisien serta manajemen pemerintahan yang baik dalam penyelenggaraan pemerintah tersebut dimulai dari tahapan perencanaan hingga pengendaliannya.

Berdasarkan Inpres nomor 7 tahun 1999 tentang Laporan Akuntabilitas Kineja Instansi Pemerintah, setiap pemerintah telah diwajibkan untuk menyusun rencana strategi lima tahun dan Laporan Akuntabilitas Kinerja Instansi Pemerintah (LAKIP) pada setiap akhir tahunnya. Namun demikian, fenomena yang muncul adalah perencanaan dan pengukuran kinerja dilakukan bersamaan pada saat menyusun LAKIP.Demikian juga dengan perumusan indikator kinerja juga dilakukan pada saat instansi menyusun LAKIP sesuai dengan kegiatan yang dilaksanakan.Akibatnya, rencana atau target kinerja umumnya juga dilakukan pada saat LAKIP tersebut disusun, termasuk dengan pengukuran kinerja sesungguhnya. Kondisi semacam ini pada gilirannya mengakibatkan antara lain:

- Laporan pertanggungjawaban selama ini hanya menekankan pada realisasi anggaran tanpa mengungkapkan hasil atau manfaat bagi stakeholders. 
- Mendorong instansi pemerintah untuk merekayasa target atau rencana kinerja untuk mendapatkan hasil capaian kinerja tertentu.

- Sulit mengukur keberhasilan atau pun kegagalan

Penilaian kinerja aparatur merupakan suatu kegiatan yang sangat penting karena dapat digunakan sebagai ukuran keberhasilan organisasi dalam mencapai misinya.

Dalam kaitan pencapaian suatu program pembangunan, pemerintah dan sosial kemasyarakatan terutama keberhasilan suatu organisasi sangatlah tergantung oleh sumber daya manusia yang disiplin, melalui pengelolaan yang baik dan terencana, karena sumber daya manusia sangat erat hubungannya dengan keberhasilan suatu organisasi melalui motivasi, kepatuhan dan sikap, atau perilaku pelaksana pembangunan itu sendiri.

Selain Kualitas Sumber Daya Manusia faktor yang tidak kalah berpengaruh adalah motivasi kerja. Motivasi berasal dari kata motif yang dapat diartikan sebagai kekuatan yang terdapat dalam diri individu, yang menyebabkan individu tersebut bertindak atau berbuat ( Uno, 2009:3). Timbulnya motivasi pada diri seseorang tentu oleh adanya suatu kebutuhan hidupnya baik itu kebutuhan primer maupun kebutuhan sekundernya. Jika kebutuhan tersebut dapat terpenuhi, maka seseorang akan giat bekerja sehingga prestasi kerja (kinerja) dapat meningkat. Kegiatan memberikan motivasi entah bagaimana cara dan dengan apa memotivasi pegawai/karyawan untuk lebih bergairah bekerja adalah fungsi dari "human relation" dalam manajemen .

\section{Kualitas Sumber Daya Manusia}

Nulhakim dan Hendriani (2002:38) membagi kualitas sumber daya manusia ke dalam dua aspek yaitu aspek fisik (kualitas fisik) yang meliputi kesehatan dan gizi, dan aspek non fisik (kualitas non fisik) antara lain kemampuan bekerja, berfikir dan keterampilan-keterampilan lain. Oleh karena itu maka upaya meningkatkan kualitas sumber daya manusia perlu diarahkan kepada dua aspek tersebut.

Kriteria untuk menentukan ukuran kualitas sumber daya manusia adalah sangat kompleks. Hal ini diungkapkan oleh Khairuddin (2000:44-45) bahwa :

Ukuran kualitas sumber daya manusia dapat dilihat dari faktor intern manusiannya, seperti: sikap mental, orientasi, wawasan berpikir dan pendidikan. Sedangkan faktor ekstern yang sesungguhnya ikut menentukan faktor intern manusia, seperti: kesehatan dan tingkat gizi suatu masyarakat, kelembagaan yang ada dan sebagainya. Memang banyak faktor yang dapat dijadikan penentu dalam membentuk kadar dan kualitas sumber daya 
manusia. Dalam hal ini, faktor yang mungkin paling utama adalah pendidikan.karena dengan pendidikanlah seseorang akan dapat memanusiakan dirinya sendiri.

Kriteria aparatur yang berkualitas akan tercermin pada dimensi pengetahuan, kemampuan/keterampilan, kemauan yang dimiliki oleh aparatur dalam melaksanakan tugas-tugasnya. Dengan demikian dimensi kualitas sumber daya manusia menurut oleh Khairuddin (2000:44-45) pada penelitian ini adalah :

1) Wawasan dan Pendidikan, yaitu mampu menguasai tugas pekerjaan, memiliki keterampilan berkomunikasi, memiliki keterampilan mengoperasikan peralatan kantor dan menguasai permasalahan kerja.

2) Sikap, yaitu disiplin dalam mejalankan tugas, tanggungjawab terhadap tugas, peka dalam menghadapi tuntutan tugas dan peduli terhadap sesama

3) Orientasi, yaitu memiliki visi dan misi kerja, memiliki semangat kerja, serta memiliki target kerja

\section{Motivasi Kerja}

Istilah motivasi (motivation) berasal dari bahasa latin, yakni movore, yang berarti "menggerakkan" (to move). Mitchel dalam Arep, Ishak \& Tanjung, Hendri. (2004:68) merumuskan istilah motivasi mewakili proses-proses psilogikal, yang menyebabkan timbulnya, diarahkannya dan terjadinya persistensi kegiatan-kegiatan sukarela (volunter) yang diarahkan ke arah tujuan tertentu. Dan As'ad. 2001: 16) menyatakan "The motivasion of people dependes on the strength of their motives.Motives are sometimes define as needs, wants or impulses within the individual".

\section{Teori motivasi "preference-expectation" atau "Pengutamaan pengharapan" dari Victor H. Vroom.}

Konsep dasar teori motivasi pengutamaan pengharapan adalah bahwa seseorang akan terdorong untuk bekerja dengan baik apabila akan memperoleh sesuatu imbalan yang pada saat itu sedang dirasakan sebagai kebutuhan pokok yang harus dipenuhi. Seorang pegawai harian yang mempunyai keluarga yang sedang sakit padahal dia sedang tidak mempunyai uang cukup untuk membeli obat, maka orang tersebut akan bersedia bekerja dengan lebih giat dari biasanya apabila dijanjikan akan diberi upah lebih banyak daripada biasanya. Apabila sedang tidak ada keluarganya yang sakit pegawai tersebut mungkin tidak 
bersedia bekerja lebih giat walaupun dijanjikan upah lebih banyak. Seorang mahasiswa yang pada suatu saat sedang memerlukan kawan akrab akan dengan senang hati apabila ada mahasiswa lain yang meminjam catatan kuliah hari itu, tetapi apabila mahasiswa tadi pada saat itu sedang tidak memerlukan kawan akrab karena memang sedang suasana gembira ria bersama kawan-kawan lainnya maka ada kemungkinan tidak akan meminjamkan bukunya dengan ikhlas.

\section{Kinerja Pegawai}

Kinerja seringkali diperdebatkan oleh para manajer dalam sebuah perusahaan, karena kinerja merupakan item atau unsur dari keberhasilan suatu organisasi atau perusahaan.Maka dari itu saat ini banyak sekali manajer yang berupaya dengan segala strategi untuk meningkatkan kinerja para bawahan atau pegawainya. Kinerjamerupakan terjemahan dari kata "performance”, yang secara umum diartikan sebagai cara dan hasil yang telah dicapai seseorang atau kelompok atau organisasi dalam melaksanakan pekerjaannya.

Kinerja adalah suatu hasil kerja yang dapat dicapai oleh seseorang atau kelompok orang dalam suatu organisasi, sesuai dengan wewenang dan tanggung jawab masing-masing, dalam rangka upaya mencapai tujuan organisasi bersangkutan secara legal, tidak melanggar hukum dan sesuai dengan moral maupun etika (Ndraha. 2005:160).

Sedangkan untuk pengukurannya kinerja diukur berdasarkan 6 aspek, sesuai dengan pendapat dari BPKP dan LAN (2002:70), pengukuran kinerja dapat dilihat dari beberapa aspek, yaitu:

1. Aspek Finansial

Aspek finansial meliputi anggaran rutin dan pembangunan dari suatu instansi pemerintah, maka aspek finansial merupakan aspek penting yang perlu diperhatikan dalam pengukuran kinerja.

2. Kepuasan Pelanggan

Dengan semakina banyaknya tuntutan masyarakat akan pelayanan yang berkualitas, maka instansi pemerintah harus benar-benar memberikan pelayanan yang berkualitas.

3. Operasi Bisnis Internal 
Informasi operasi binis internal diperlukan untuk memastikan bahwa seluruh kegiatan instansi pemerintah sudan in-corn (seirama) untuk mencapai tujuan dan sasaran organisasi seperti yang tercantum dalam rencana strategis.

4. Kepuasan Pegawai

Dalam setiap organisasi, pegawai merupakan asset yang harus dikelola dengan baik. Apabila pegawai tidak terkelola dengan baik, maka kehancuran dari instansi pemerintah sungguh sulit untuk dicegah.

5. Kepuasan Komunitas

Instansi pemerintah tidak beroperasi artinya kegiatan instansi pemerintah berinteraksi dengan berbagai pihak yang menaruh kepentingan terhadap keberadaannya.

6. Waktu

Ukuran waktu juga merupakan variabel yang perlu diperhatikan dalam desain pengukuran kinerja. Betapa sering kita membutuhkan informasi untuk pengambilan keputusan, namun informasi tersebut lambat diterima. Sebaliknya informasi yang ada sudah tidak relevan.

\section{Efektivitas Organisasi}

Organisasi yang berhasil dapat diukur dengan melihat pada sejauhmana organisasi tersebut dapat mencapai tujuan yang sudah ditetapkan.Konsep Efektifitas yang dikemukakan para ahli organisasi dan manajemen memiliki makna yang berbeda, tergantung pada kerangka acuan yang dipergunakan.

Menurut Edwin Flippo bahwa efektivitas adalah yang berhubungan dengan tujuan organisasi baik secara explisit maupun implisit. Sampai beberapa jauh pencapaian tujuan organisasi sesuai seperti yang direncanakan (Mas'ud, 2000 : 41). Sementara itu Soedjadi (2002 : 37) mengemukakan bahwa efektivitas adalah melakukan kegiatan pada waktu yang tepat dalam arti target tercapai sesuai dengan waktu yang ditetapkan (target achieved).

Emerson dalam Handayaningrat (2003:16) mengatakan bahwa Effectiveness is "measuring in a term of attaining prescribed goals or 
objectives." (Pengukuran dalam arti tercapainya sasaran atau tujuan yang telah ditentukan sebelumnya)

Pendapat Emitai Etzioni yang dikutip Adam I. Indrawijaya (2000:227) mengemukakan pendekatan pengukuran efektivitas organisasi yang disebutnya SYSTEM MODEL, mencakup empat kriteria, yaitu adaptasi, integrasi, motivasi, dan produksi. Pertama, Pada kriteria adaptasi dipersoalkan kemampuan suatu organisasi untuk menyusuaikan diri dengan lingkungannya. Kedua, adalah integrasi, yaitu pengukuran terhadap tingkat kemampuan suatu organisasi untuk mengadakan sosialisasi, pengembangan konsensus dan komunikasi dengan berbagai macam organisasi lainnya.

Kriteria ketiga adalah motivasi anggota, Dalam kriteria ini dilakukan pengukuran mengenai keterikatan dan hubungan antara pelaku organisasi dengan organisasinya dan kelengkapan sarana bagi pelaksanaan tugas pokok dan fungsi organisasi. Kriteria keempat adalah produksi, yaitu usaha pengukuran efektivitas organisasi dihubungkan dengan jumlah dan mutu keluaran organisasi serta intensitas kegiatan suatu organisasi.

\section{Kerangka Pemikiran}

\section{Pengaruh Kualitas Sumber Daya Manusia Terhadap kinerja pegawai}

Ulasan mengenai pengaruh kualitas sumber daya manusia terhadap kinerja pegawai telah dikemukakan oleh Mc.Clelland dalam Cira dan Benjamin (1998), dengan mengevaluasi kompetensi-kompetensi yang dimiliki seseorang, kita akan dapat memprediksikan kinerja orang tersebut. Kompetensi sumber daya manusia dapat digunakan sebagai kriteria utama untuk menilai kerja seseorang.

Pemaparan diatas menggambarkan bahwa efektifitas organisasi dipengaruhi oleh berbagai faktor diantaranya adalah faktor kinerja pegawai.Kinerja pegawai yang baik akan sangat mempermudah suatu perusahaan atau organisasi untuk mencapai tujuan yang diinginkan, maka kerangka pemikiran penelitian ini digambarkan pada alur pikir sebagai berikut : 


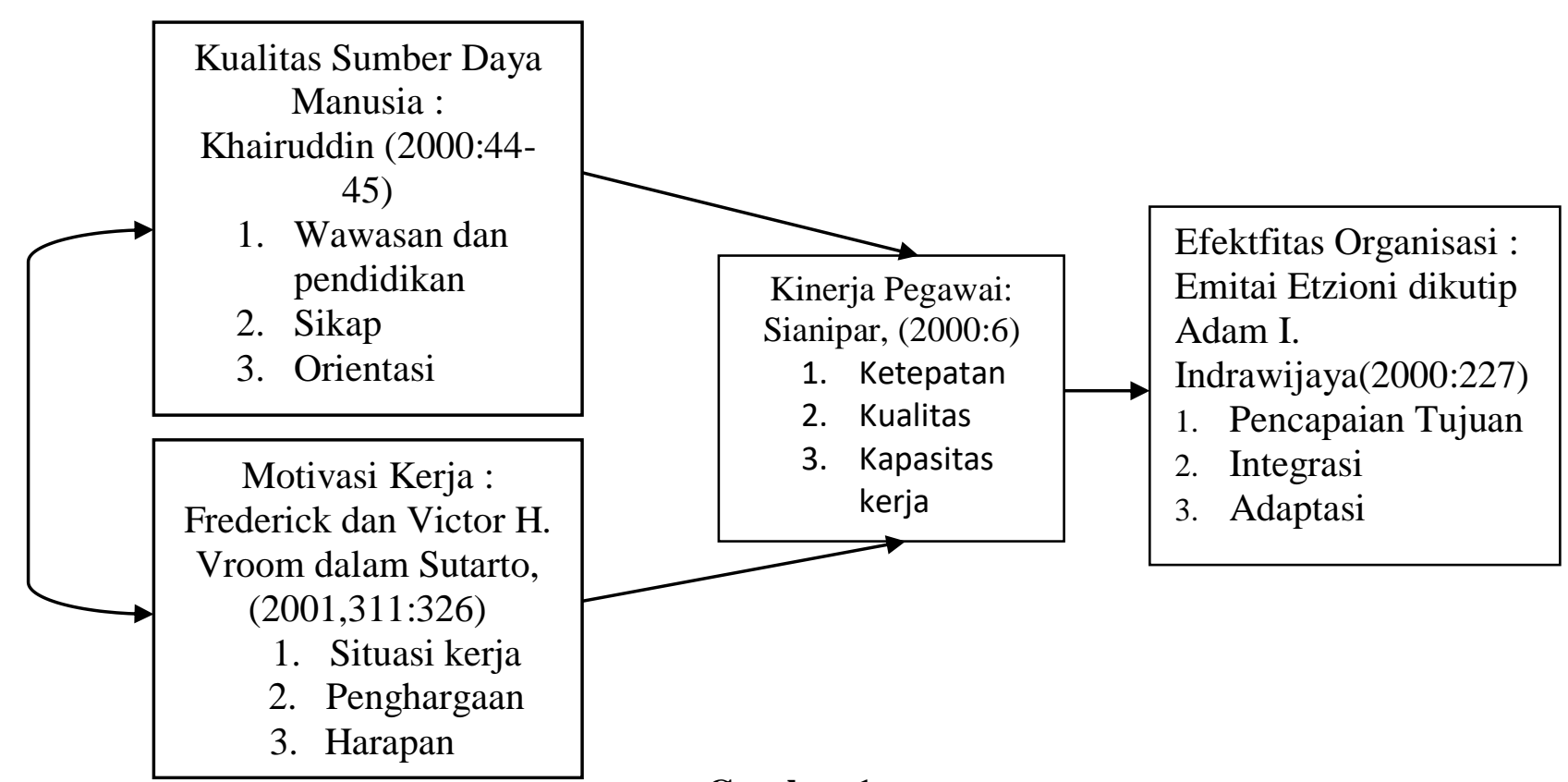

\section{Gambar 1}

Kerangka Pemikiran

\section{Hipotesis Penelitian}

Hipotesis adalah dugaan/pernyataan sementara yang diungkapkan secara deklaratif/yang menjadi jawaban dari sebuah permasalahan. Adapun hipotesis pada penelitian ini adalah :

1. Pengaruh kualitas sumber daya manusia terhadap kinerja pegawai pada Bagian Kesejahteraan Rakyat Sekretariat Daerah Kabupaten Karawang, adalah positif dan signifikan.

2. Pengaruh motivasi kerja terhadap kinerja pegawai pada Bagian Kesejahteraan Rakyat Sekretariat Daerah Kabupaten Karawang, adalah positif dan signifikan.

3. Pengaruh kualitas sumber daya manusia dan motivasi kerja secara simultan terhadap kinerja pegawai pada Bagian Kesejahteraan Rakyat Sekretariat Daerah Kabupaten Karawang,adalah positif dan signifikan.

4. Pengaruh kinerja pegawai terhadap efektifitas organisasi pada Bagian Kesejahteraan Rakyat Sekretariat Daerah Kabupaten Karawang adalah positif dan signifikan. 


\section{Metode Yang Digunakan}

Metode yang digunakan dalam penelitian ini menggunakan metode penelitian deskriptif dan verifikatif. Penelitian deskriptif adalah penelitian yang dilakukan untuk mengetahui nilai variable mandiri, baik satu variable atau lebih ( independent) dengan menghubungkan antara variabel satu dengan variabel yang lain (Sugiono 2007:11). Penelitian ini bertujuan untuk memperoleh gambaran mengenai pengaruh kualitas sumber daya manusia dan motivasi kerja terhadap kinerja pegawai dan dampaknya terhadap efektifitas organisasi pada Bagian Kesra Setda Kabupaten Karawang.

\section{Analisis Verifikatif}

Metode analisis yang digunakan dalam penelitian ini adalah analisis jalur. Analisis jalur adalah suatu teknik untuk menganalisis hubungan sebab akibat yang terjadi pada regresi berganda jika variabel bebasnya mempengaruhi variabel tergantung tidak hanya secara langsung, tetapi juga secara tidak langsung (Pardede:2014,16).

Dengan demikian variabel yang digunakan dalam penelitian variable X1 Kualitas Sumber Daya Manusia (Eksogen) dan varibael X2 Motivasi kerja (eksogen) terhadap variable Y kinerja pegawai (endogen) dan dampaknya terhadap variable $\mathrm{Z}$ efektifitas organisasi, terlihat dari path analisys sebagai berikut:

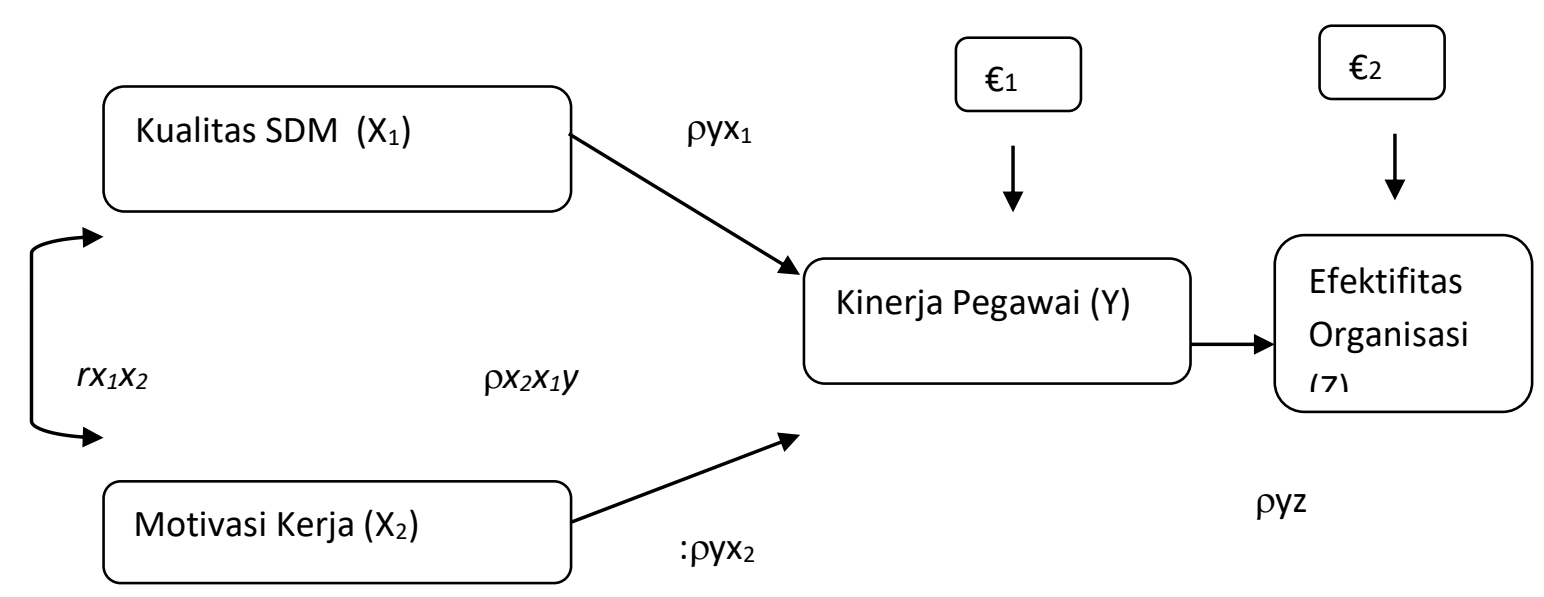

Gambar 2 Analisis Jalur 
Keterangan:

X1 = Kualitas SDM (Sumber Daya Manusia)

$\mathrm{X} 2$ = Motivasi kerja

$\mathrm{Y}=$ Kinerja Pegawai

$\mathrm{Z}=$ Efektifitas Organisasi

$r \mathrm{X}_{1} \mathrm{X}_{2}=$ Korelasi antara kualitas SDM dengan motivasi kerja

$\rho \mathrm{YX}_{1}=$ Pengaruh parsial kualitas sumber daya manusia terhadap kinerja pegawai

$\rho \mathrm{YX}_{2}=$ Pengaruh Parsial motivasi kerja terhadap kinerja pegawai

$\rho \mathrm{YX}_{1} \mathrm{X}_{2}=$ Pengaruh simultan kualitas sumber daya manusia dan motivasi kerja terhadap kinerja pegawai

$\rho Y Z=$ Pengaruh kinerja pegawai terhadap efektifitas organisasi

$€=$ Pengaruh variable lain

\section{Hasil Penelitian}

\section{Hasil Penelitian Deskriptif}

Rekapitulasi Hasil Deskriptif Variabel Kualitas Sumber Daya Manusia

Hasil analisis variabel kualitas sumber daya manusia berada dalam skala baik dan dapat dideskripsikan dalam rentang skala sebagai berikut :

\begin{tabular}{|c|c|c|c|c|c|}
\hline & & & & B & SB \\
\hline \multirow[t]{2}{*}{100,0} & \multirow[t]{2}{*}{180,0} & \multirow[t]{2}{*}{260,0} & 340,0 & \multirow[t]{2}{*}{420,0} & \multirow[t]{2}{*}{500,0} \\
\hline & & & 340,6 & & \\
\hline
\end{tabular}

Gambar 3

Rentang Skala Variabel Kualitas Sumber Daya Manusia Pada Bagian Kesra Setda Kabupaten Karawang

Pada gambar 3 terlihat bahwa variable kualitas sumber daya manusia Pada Bagian

Kesra Setda Kabupaten Karawang berada pada rentang skala 340 - 420 dengan kriteria baik.

Hasil analisis variabel motivasi kerja berada dalam skala baik dan dapat dideskripsikan dalam rentang skala sebagai berikut : 


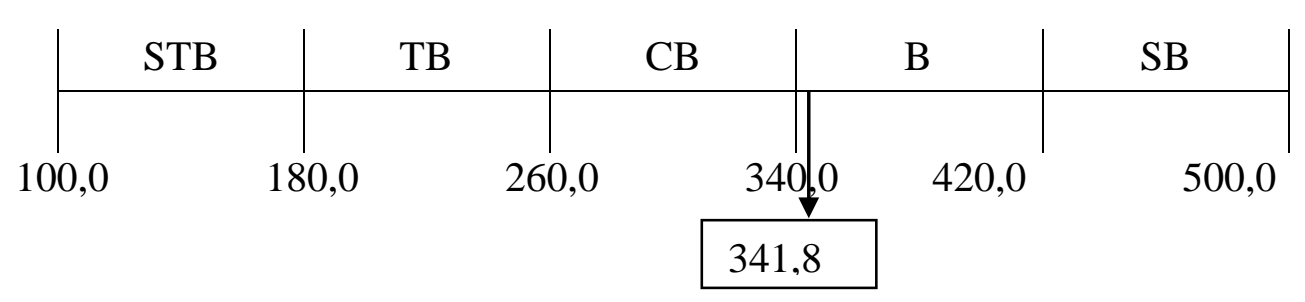

\section{Gambar 4}

Rentang Skala Variabel Motivasi Kerja Bagian Kesra Setda Kabupaten Karawang

Pada gambar 4 terlihat bahwa variabele motivasi kerja berada pada rentang skala 340 - 420 dengan kriteria baik.

Hasil analisis variabel kinerja pegawai berada dalam skala baik dan dapat dideskripsikan dalam rentang skala sebagai berikut :

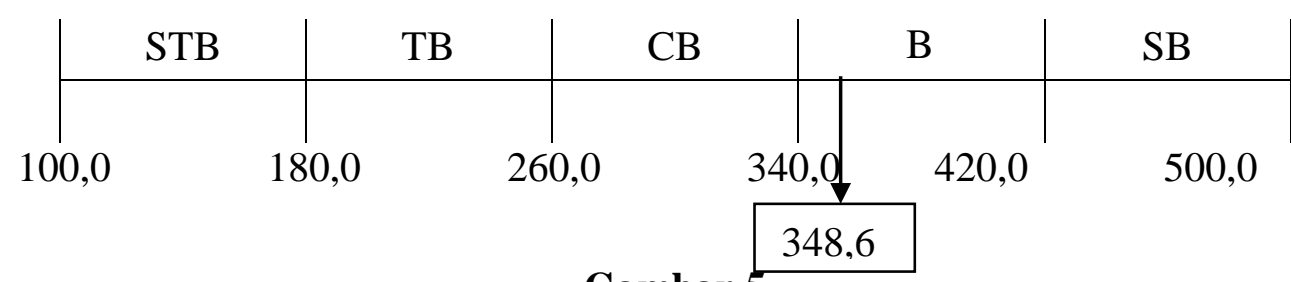

Gambar 5

Rentang Skala Variabel Kinerja Pegawai (Y)

Pada gambar 5 terlihat bahwa variabel kinerja pegawai berada pada rentang skala 340 - 420 dengan kriteria baik

\section{Persepsi Responden Tentang Variabel Efektifitas Organisasi Pada Bagian}

\section{Kesejateraan Rakyat Setda Kabupaten Karawang.}

Hasil analisis variabel efektifitas organisasi dalam skala baik dan dapat dideskripsikan dalam rentang skala sebagai berikut :

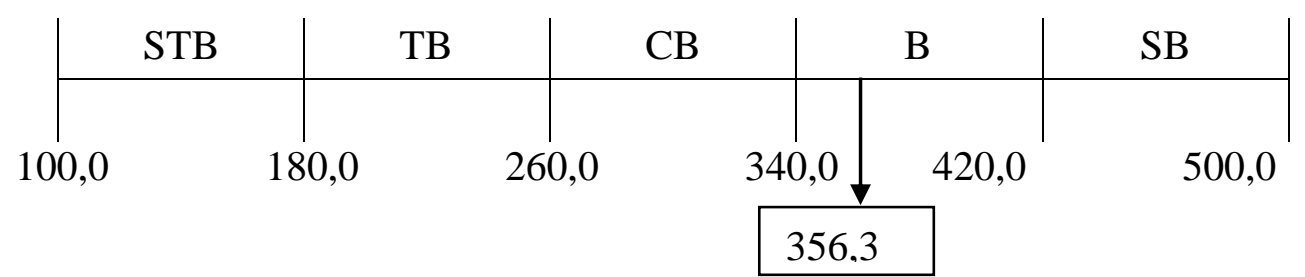

\section{Gambar 6}

Rentang Skala Variabel Efektifitas Organisasi Bagian Kesra Setda Kabupaten Karawang

Pada gambar 6 terlihat bahwa variable efektifitas organisasi berada pada rentang skala 340 - 420 dengan kriteria baik.

\section{Analisis Data Verifikatif dan Uji Hipotesis}




\section{Besaran Hubungan Antara Variabel Kualitas Sumber Daya Manusia (X1) dan Motivasi Kerja (X2)}

Berdasarkan hasil output SPSS 20.0 hubungan kedua variabel bebas dapat dijelaskan sesuai tabel korelasi di bawah ini :

Tabel Korelasi Variabel Bebas

\begin{tabular}{|ll|r|r|}
\hline & \multicolumn{1}{|c|}{$\begin{array}{c}\text { Kualitas } \\
\text { SDM }\end{array}$} & \multicolumn{1}{c|}{$\begin{array}{c}\text { Kotivasi } \\
\text { Kerja }\end{array}$} \\
\hline Kualitas & Pearson Correlation & 1 & $.687^{* *}$ \\
SDM & Sig. (2-tailed) & & .000 \\
& $\mathrm{~N}$ & 100 & 100 \\
Motivasi & Pearson Correlation & $.687^{* *}$ & 1 \\
Kerja & Sig. (2-tailed) & .000 & 100 \\
\hline
\end{tabular}

**. Correlation is significant at the 0.01 level (2-tailed).

Sumber :hasil pengolahan data SPSS, 2016

Untuk lebih jelasnya hubungan antara kedua variabel bebas tersebut dapat dijelaskan pada gambar di bawh hini .

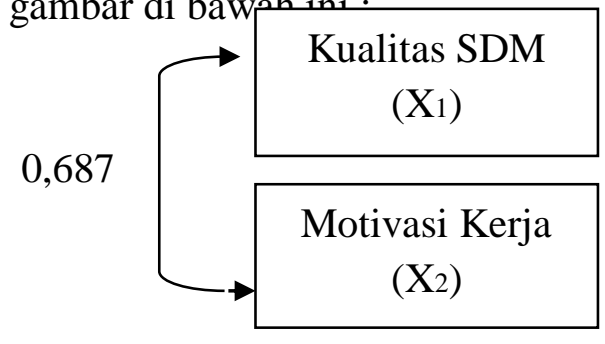

Hubungan diantara Variabel Bebas

Dari hasil analisis diperoleh besaran koefisien korelasi diantara variable bebas yaitu hubungan antara variable kualitas sumber daya manusia (X1) dengan motivasi kerja (X2) didapat nilai sebesar 0,687 yang berarti mempunyai tingkat hubungan yang kuat dan positif. Nilai signifikasi $0,000<0,05$ menunjukan korelasi yang signifikan. Berdasarkan Sugiyono (2012) bahwa nilai 0,687 adalah hubungan yang kuat

\section{Analisis Jalur}

Berdasarkan hasil pengolahan data di dapatkan koefisien jalur untuk variabel Kualitas SDM (X1) dan motivasi pegawai (X2) terhadap Kinerja Pegawai (Y) diperoleh hasil sebagai berikut :

Tabel Koefisien Jalur Kualitas SDM (X1) dan Motivasi Kerja (X2) 
terhadap Kinerja Pegawai (Y)

\begin{tabular}{|c|c|c|c|c|c|c|}
\hline \multirow{2}{*}{\multicolumn{2}{|c|}{ Model }} & \multicolumn{2}{|c|}{$\begin{array}{c}\text { Unstandardized } \\
\text { Coefficients }\end{array}$} & \multirow{2}{*}{$\begin{array}{l}\text { Standardized } \\
\text { Coefficients } \\
\text { Beta }\end{array}$} & \multirow[t]{2}{*}{$\mathrm{t}$} & \multirow[t]{2}{*}{ Sig. } \\
\hline & & B & Std. Error & & & \\
\hline \multirow{3}{*}{1} & (Constant) & 7.612 & 1.908 & & 3.990 & .000 \\
\hline & $\begin{array}{l}\text { Kualitas } \\
\text { SDM }\end{array}$ & .331 & .058 & .350 & 5.662 & .000 \\
\hline & $\begin{array}{l}\text { Motivasi } \\
\text { Kerja }\end{array}$ & .562 & .056 & .620 & 10.039 & .000 \\
\hline
\end{tabular}

a. Dependent Variable: Kinerja Pegawai

Sumber :hasil pengolahan data SPSS, 2016

Sedangkan untuk koefisien jalur kinerja pegawai (Y) terhadap efektifitas organisasi (Z) diperoleh hasil sebagai berikut :

Tabel Koefisien Jalur Kinerja pegawai (Y) terhadap Efektifitas Organisasi (Z)

\begin{tabular}{|c|c|c|c|c|c|c|}
\hline \multirow{2}{*}{\multicolumn{2}{|c|}{ Model }} & \multicolumn{2}{|c|}{$\begin{array}{c}\text { Unstandardized } \\
\text { Coefficients }\end{array}$} & $\begin{array}{c}\text { Standardized } \\
\text { Coefficients } \\
\end{array}$ & \multirow[t]{2}{*}{$\mathrm{t}$} & \multirow[t]{2}{*}{ Sig. } \\
\hline & & B & Std. Error & Beta & & \\
\hline \multirow[b]{2}{*}{1} & (Constant) & -.053 & 2.290 & \multirow[b]{2}{*}{.889} & \multirow{2}{*}{$\begin{array}{r}-.023 \\
19.248\end{array}$} & \multirow{2}{*}{$\begin{array}{l}.981 \\
.000\end{array}$} \\
\hline & $\begin{array}{l}\text { Kinerja } \\
\text { Pegawai }\end{array}$ & .963 & .050 & & & \\
\hline
\end{tabular}

a. Dependent Variable: Efektifitas organisasi

Sumber :hasil pengolahan data SPSS, 2016

\section{Koefisien Jalur Variabel Kualitas SDM (X1) terhadap Kinerja Pegawai}

(Y) Pada Bagian Kesra Setda Kabupaten Karawang.

Berdasarkan hasil perhitungan statistik di atas diperoleh besaran koefisien jalur Kualitas SDM (X1) dengan Kinerja Pegawai (Y) pada Bagian Kesra Setda Kabupaten Karawang adalah sebesar $r=0,350$ atau $\rho X 1 Y=0,350$ sehingga diperoleh persamaan $\mathbf{Y}=\mathbf{0 , 3 5} \mathbf{X}_{\mathbf{1}}$

2. Koefisien Jalur Variabel Kualitas Motivasi Kerja (X2) terhadap Kinerja Pegawai (Y) Pada Bagian Kesra Setda Kabupaten Karawang. 
Berdasarkan tabel 4.76 diperoleh nilai koefisien jalur Motivasi kerja (X2) dengan Kinerja Pegawai (Y) pada Bagian Kesra Setda Kabupaten Karawang adalah sebesar $\rho X 2 Y=0,620$, sehingga diperoleh persamaan $Y=0,62 X_{2}$

\section{Koefisien Jalur Variabel Kinerja pegawai (Y) terhadap Efektifitas organisasi (Z) Pada Bagian Kesra Setda Kabupaten Karawang.}

Berdasarkan tabel 4.77 diperoleh nilai koefisien jalur Kinerja pegawai (Y) terhadap Efektifitas organisasi $(Z)$ pada Bagian Kesra Setda Kabupaten Karawang adalah sebesar $\rho \mathrm{X} 2 \mathrm{Y}=0,620$, sehingga diperoleh persamaan $\mathrm{Z}=0,889 \mathrm{Y}$

Hasil pengujian analisis jalur secara keseluruhan dapat digambarkan seperti yang tampak pada gambar dibawah ini :

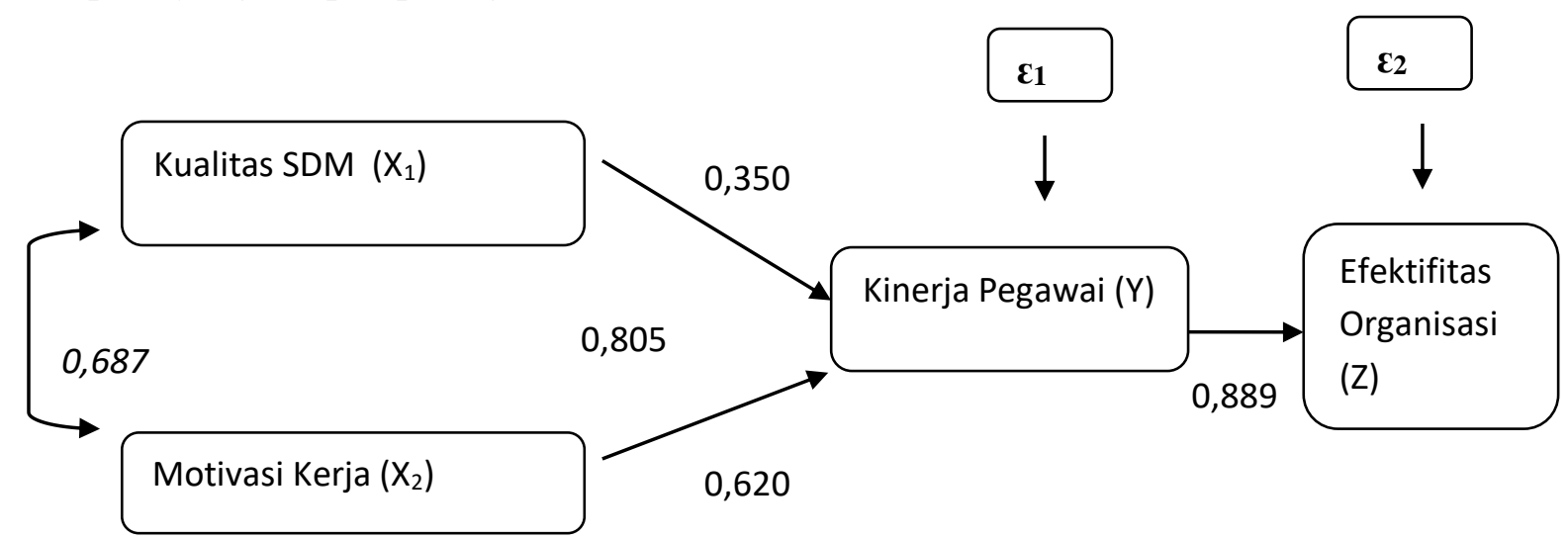

Berdasarkan gambar diatas dapat dilihat untuk masing-masing variabel bebas terhadap variabel terikat bahwa besaran koefisien jalur variabel Motivasi kerja (X2) lebih tinggi dari variabel Kualitas SDM (X1), artinya Motivasi kerja (X2) lebih berpengaruh terhadap Kinerja pegawai (Y) dibandingkan Kuaitas SDM (X1), sehingga untuk persamaan jalurnya, yaitu :Z $=\mathbf{0 , 3 5}$ X1 + 0,62 X2 + 0,889 $\mathbf{Y}+\varepsilon_{1}+\varepsilon_{2}$

Pengaruh Variabel Kualitas SDM (X1) dan Motivasi Kerja (X2) terhadap Kinerja pegawai (Y)

Pengaruh langsung dan tidak langsung secara bersamaan dari variabel Kualitas SDM (X1) dan Motivasi Kerja (X2) terhadap Kinerja pegawai (Y) pada Bagian Kesra Setda Kabupaten Karawang dapat dilihat pada tabel berikut :

Tabel Pengaruh Simultan Kualitas SDM (X1) dan Motivasi Kerja (X2) terhadap Kinerja Pegawai (Y) Pada Bagian Kesra Setda Kabupaten Karawang 


\begin{tabular}{|c|c|c|c|c|c|}
\hline \multirow[b]{2}{*}{ Hubungan } & \multirow{2}{*}{$\begin{array}{l}\text { Koefisien } \\
\text { Jalur }\end{array}$} & \multirow{2}{*}{$\begin{array}{l}\text { Pengaruh } \\
\text { langsung }\end{array}$} & \multicolumn{2}{|c|}{ Pengaruh Tidak Langsung } & \multirow{2}{*}{$\begin{array}{c}\text { Sub } \\
\text { Total } \\
\text { Pengaruh }\end{array}$} \\
\hline & & & X1 & $\mathrm{X} 2$ & \\
\hline $\begin{array}{l}\text { Pengaruh } \\
\text { X1 } \\
\text { terhadap } \\
\text { Y }\end{array}$ & 0 , & $\begin{array}{l}\mathbf{r}^{2}= \\
(0,35 * 0,35) \\
=0,123\end{array}$ & & $\begin{array}{l}(0,35)(0,687) \\
(0,62)= \\
0,149\end{array}$ & 0,272 \\
\hline $\begin{array}{c}\text { Pengaruh } \\
\text { X2 } \\
\text { terhadap } \\
\text { Y }\end{array}$ & 0,62 & $\begin{array}{l}\mathrm{r}^{2}= \\
(0,62 * 0,62) \\
=0,384\end{array}$ & $\begin{array}{l}(0,62)(0,687) \\
(0,35) \\
0,149\end{array}$ & & 0,533 \\
\hline \multicolumn{4}{|c|}{ Total Pengaruh Simultan } & \multicolumn{2}{|c|}{$0,805 \times 100 \%=80,5 \%$} \\
\hline Penga & h variab & $\operatorname{lain}(\varepsilon)$ & & $1-0,805=0,1$ & $5=19,5 \%$ \\
\hline
\end{tabular}

Sumber : hasil pengolahan data, 2016

Berdasarkan tabel di atas dapat diketahui bahwa pengaruh langsung X1 terhadap Y sebesar 0,123 atau 12,3\%, pengaruh tidak langsung X1 melalui X2 terhadap Y sebesar 0,149 atau 14,9\%. Pengaruh langsung X2 terhadap Y sebesar 0,384 atau $38,4 \%$, pengaruh tidak langsung $\mathrm{X} 2$ melalui $\mathrm{X} 1$ terhadap $\mathrm{Y}$ sebesar 0,149 atau $14,9 \%$. Total pengaruh yang disebakan X1 dan X2 secara bersama-sama terhadap $\mathrm{Y}$ adalah sebesar 0,805 atau 80,5\%. Adapun sisanya sebesar $19.5 \%(100 \%-80,5$ $\%)$ merupakan kontribusi variabel lain $(\varepsilon)$ yang tidak diteliti

\section{Pengaruh Variabel Kinerja pegawai (Y) terhadap Efektifitas Organisasi (Z)}

Pengaruh langsung dari variabel Kinerja pegawai (Y) terhadap Efektifitas organisasi (Z) berdasarkan pengolahan data SPSS adalah sebesar 0,79 atau 79\%. Adapun sisanya sebesar 21\% (100\% - 79\%) merupakan kontribusi variabel lain (ع) yang tidak diteliti.

Total pengaruh dari variabel Kualitas SDM (X1) dan Motivasi kerja (X2) terhadap Kinerja pegawai $(\mathrm{Y})$ dinyatakan oleh koefisien determinasi $\left(\mathrm{R}^{2}\right)$. Nilai koefisien determinasi $\left(\mathrm{R}^{2}\right)$ diperoleh hasil sebesar 0,805 sebesar 80,5\%. Angka tersebut merupakan angka besarnya pengaruh Kualitas SDM (X1) dan Motivasi kerja (X2) secara simultan terhadap Kinerja pegawai (Y) pada Bagian Kesra Setda Kabupaten Karawang dengan cara menghitung Koefisien Determinasi (KD) dengan menggunakan rumus sebagai berikut :

$$
\begin{aligned}
& \mathrm{KD}=\mathrm{r}^{2} \times 100 \% \\
& \mathrm{KD}=0,805 \times 100 \% \\
& \mathrm{KD}=80,5 \%
\end{aligned}
$$


Angka tersebut mempunyai arti bahwa pengaruh Kualitas SDM dan Motivasi kerja secara simultan terhadap Kinerja pegawai pada Bagian Kesra Setda Kabupaten Karawang adalah 80,5 \%, sedangkan sisanya sebesar 19,5\% merupakan kontribusi variabel lain $(\varepsilon)$ yang tidak diteliti.

Analisis Koefisien Determinan $\left(\mathbf{R}^{2}\right)$ Kinerja pegawai $(Y)$ terhadap Efektifitas $\operatorname{organisasi}(\mathbf{Z})$

Pengaruh dari variabel Kinerja pegawai (Y) terhadap Efektifitas organisasi (Z)dinyatakan dinyatakan oleh koefisien determinasi $\left(\mathrm{R}^{2}\right)$. Nilai koefisien determinasi $\left(\mathrm{R}^{2}\right)$ kinerja pegawai $(\mathrm{Y})$ terhadap Efektifitas organisasi $(\mathrm{Z})$ sebesar 0.791, artinya besaran pengaruh antara Kinerja Pegawai dengan Efektifitas organisasi pada Bagian Kesra Setda Kabupaten Karawang adalah sebesar r =0,889 atau $r^{2}=0,79=79 \%$. Dengan demikian, pengaruh Kinerja pegawai terhadap Efektifitas organisasi adalah sangat kuat (antara 0,80 - 1,0), Sugiyono, (2007).

Koefisien jalur $\varepsilon$ (variabel diluar model) adalah:

$\varepsilon \rho \mathrm{YZ}=\sqrt{(1-0.791)}=0,451$ atau $\mathrm{r}^{2}=0,2025=20,25 \%$.

koesfisien jalur pengaruh kinerja pegawai (Y) terhadap Efektifitas Organisasi (Z) dan pengaruh variabel lain diluar variabel penelitian dapat dilihat sebagaimana berikut ini :

$\varepsilon$

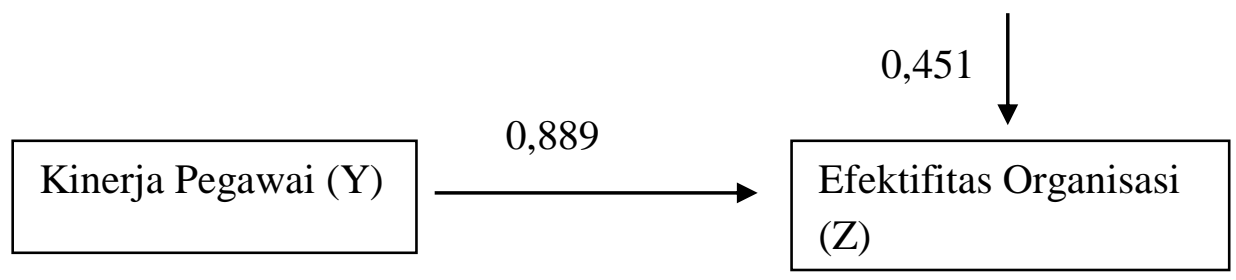

Model Pengaruh Parsial Kinerja Pegawai (Y) terhadap Efektifitas Organisasi (Z) Pada Bagian Kesra Setda Kabupaten Karawang

\section{Uji Hipotesis}

1. Hipotesis Pengaruh Parsial Parsial Kualitas Sumber Daya Manusia (X1) terhadap terhadap Kinerja Pegawai (Y) Pada Bagian Kesra Setda Kabupaten Karawang.

Berdasarkan hasil uji keberartian terhadap koefisien korelasi diperoleh nilai $\mathrm{t}$ ${ }_{\text {hitung }}=5,662>\mathrm{t}_{\text {tabel }}=3,1777$ dengan tingkat signifikan dibawah 0,05 yaitu 
0,0002. Sehingga dapat disimpulkan bahwa kualitas SDM (X1) berpengaruh positif terhadap kinerja pegawai (Y) pada Bagian Kesra Setda Kabupaten Karawang.Selain itu dengan membandingkan angka signifikansi penelitian 0,000 $<0,05$, maka dapat disimpulkan Ho ditolak dan Hi diterima.

\section{Hipotesis Pengaruh Parsial Motivasi kerja (X2), terhadap Kinerja Pegawai} (Y) Pada Bagian Kesra Setda Kabupaten Karawang.

Berdasarkan hasil uji keberartian terhadap koefisien korelasi diperoleh nilai $t$ ${ }_{\text {hitung }}=10,039>\mathrm{t}{ }_{\text {tabel }}=3,1777$ dengan tingkat signifikan dibawah 0,05 yaitu 0,0002,sehingga dapat disimpulkan bahwa motivasi kerja (X2) berpengaruh positif terhadap kinerja pegawai (Y) pada Bagian Kesra Setda Kabupaten Karawang. Selain itu dengan membandingkan angka signifikansi penelitian 0,000 $<$ 0,05, maka dapat disimpulkan Ho ditolak dan Hı diterima.

\section{Hipotesis Pengaruh simultan Kualitas SDM (X1) dan Motivasi kerja (X2), terhadap Kinerja Pegawai (Y) Pada Bagian Kesra Setda Kabupaten Karawang.}

Dengan membandingkan besarnya angka $\mathrm{F}$ penelitian dengan $\mathrm{F}$ table, dimana $\mathrm{F}$ penelitian dari SPSS sebesar 199.667 > F tabel sebesar 3.097 dan cara kedua ialah dengan membandingkan angka taraf signifikansi (Sig.) hasil penghitungan dengan taraf signifikansi 0,05 (5\%) diperoleh Sig.0,000 $<\alpha 5 \%$, sehingga berdasarkan hasil yang diperoleh tersebut, maka Ho ditolak dan $\mathrm{H}_{1}$ diterima. Artinya terdapat pengaruh yang signifikan antara Kualitas SDM dan Motivasi kerja terhadap Kinerja pegawai pada Bagian Kesra Setda Kabupaten Karawang.

\section{Hipotesis Pengaruh Kinerja pegawai (Y) terhadap Efektifitas Organisasi (Z)} Pada Bagian Kesra Setda Kabupaten Karawang.

Berdasarkan hasil uji keberartian terhdap koefisien korelasi diperoleh nilai $\mathrm{t}$ hitung $=19,248>\mathrm{t}_{\text {tabel }}=3,1777$ dengan tingkat signifikan dibawah 0,05 yaitu 0,0002,sehingga dapat disimpulkan bahwa kinerja pegawai berpengaruh positif terhadap efektifitas organisasi pada Bagian Kesra Setda Kabupaten Karawang. 
Selain itu dengan membandingkan angka signifikansi penelitian 0,000 0,05, maka dapat disimpulkan Ho ditolak dan $\mathrm{H}$ diterima.

\section{Pembahasan Hasil Penelitian}

Berdasarkan hasil pengujian dan analisis penelitian di atas, dapat dilakukan pembahsan sebagai berikut :

\section{Pembahasan Deskriptif}

\section{Kualitas Sumber Daya Manusia PadaBagian Kesejahteraan Rakyat Sekeretariat Daerah Kabupaten Karawang.}

Hasil penelitian membuktikan bahwaKualitas Sumber Daya Manusia pada Bagian Kesejahteraan Rakyat Sekretariat Daerah Kabupaten karawang berada pada kriteria skala baik.Hal ini ditunjukkan dari hasil penelitian dengan menggunakan rentang skala dengan mendapatkan skor rata-rata dengan kategori baik. Fakta ini menggambarkan bahwa kualitas sumber daya manusia pada Bagian Kesejahteraan Rakyat Sekretariat Daerah Kabupaten Karawang yang terdiri dari dimensi wawasan, pendidikan, sikap dan orientasi masih dinilai baik. Namun dari ke-empat dimensi tersebut masih ada yang nilainya masih kurang yaitu dimensi sikap, tetapi masih dalam kriteria cukup baik.

\section{Motivasi Kerja PadaBagian Kesejahteraan Rakyat Sekeretariat Daerah Kabupaten Karawang}

Hasil penelitian membuktikan bahwaMotivasi Kerja pada Bagian Kesejahteraan Rakyat Sekretariat Daerah Kabupaten karawang berada pada kriteria skala baik.Hal ini ditunjukkan dari hasil penelitian dengan menggunakan rentang skala dengan mendapatkan skor rata-rata dengan kategori baik. Fakta ini menggambarkan bahwa motivasi kerja pada Bagian Kesejahteraan Rakyat Sekretariat Daerah Kabupaten Karawang yang terdiri dari dimensi situasi kerja, penghargaan, dan harapan masih dinilai baik. Dari ketiga dimensi tersebut masih ada yang nilainya masih kurag yaitu dimensi harapan, namun masih dalam kriteria cukup baik.

Mengacu pada teori motivasi "preference-expectation" atau "Pengutamaan pengharapan" dari Victor H. Vroom, dimana konsep dasar teori motivasi 
pengutamaan pengharapan adalah bahwa seseorang akan terdorong untuk bekerja dengan baik apabila akan memperoleh sesuatu imbalan yang pada saat itu sedang dirasakan sebagai kebutuhan pokok yang harus dipenuhi.

\section{Kinerja Pegawai PadaBagian Kesejahteraan Rakyat Sekretariat Daerah Kabupaten Karawang}

Hasil penelitian membuktikan bahwaKinerja pegawai Manusia pada Bagian Kesejahteraan Rakyat Sekretariat Daerah Kabupaten karawang berada pada kriteria skala baik. Hal ini ditunjukkan dari hasil penelitian dengan menggunakan rentang skala dengan mendapatkan skor rata-rata dengan kategori baik. Fakta ini menggambarkan bahwa kinerja pegawai pada Bagian Kesejahteraan Rakyat Sekeretariat Daerah Kabupaten Karawang yang terdiri dari dimensi ketepatan kerja, dimensi kualitas kerja dan dimensi kapasitas kerja masih dinilai baik. Dari ketiga dimensi tersebut masih ada yang nilainya masih kurang yaitu dimensi kualitas kerja, namun masih dalam kriteria cukup baik. Hal ini menunjukan bahwa secara kuantitas kinerja pegawai pada Bagian Kesejahteraan Rakyat Sekeretariat Daerah Kabupaten Karawang dinilai baik, namun secara kualitas masih kurang optimal.

Menurut Hernt dan Obsan (1991: 59), secara formal performance atau kinerja didefinisikan sebagai kuantitas dan kualitas pencapaian tugas, baik yang dilakukan oleh individu, kelompok ataupun organisasi.Aspek kuantitas menunjukan beban kerja yang ditetapkan dalam uraian kerja, sedangkan kualitas kerja dapat dilihat dari rapi atau tidaknya hasil yang dicapai.

\section{Efektifitas Organsisasi PadaBagian Kesejahteraan Rakyat Sekretariat Daerah Kabupaten Karawang}

Hasil penelitian membuktikan bahwaEfektifitas organisasi pada Bagian Kesejahteraan Rakyat Sekretariat Daerah Kabupaten karawang berada pada kriteria skala baik. Hal ini ditunjukkan dari hasil penelitian dengan menggunakan rentang skala dengan mendapatkan skor rata-rata dengan kategori baik. Fakta ini menggambarkan bahwa efektifitas organisasi pada Bagian Kesejahteraan Rakyat Sekeretariat Daerah Kabupaten Karawang yang terdiri dari dimensi produksi, dimensi integrasi, dimensi adaptasi dan dimensi motivasi masih dinilai baik.

\section{Pembahasan Verifikatif}




\section{Pengaruh Kualitas Sumber Daya Manusia Terhadap Kinerja Pegawai} Bagian Kesejahteraan Rakyat Sekeretariat Daerah Kabupaten Karawang

Hasil penelitian membuktikan bahwa pengaruh Kualitas SDM terhadap Kinerja pegawai pada Bagian Kesejahteraan Rakyat Sekeretariat Daerah Kabupaten Karawang adalah positif dan signifikan. Fakta ini mengisyaratkan bahwa apabila Kualitas SDM ditingkatkan atau meningkat, maka peningkatan ini akan dibarengi dengan peningkatan Kinerja pegawai pada Bagian Kesejahteraan Rakyat Sekeretariat Daerah Kabupaten Karawang. Dan apabila kulaitas SDM diturunkan atau menurun, maka penurunan ini akan dibarengi dengan penurunan kinerja pegawai pada Bagian Kesejahteraan Rakyat Sekeretariat Daerah Kabupaten Karawang.

\section{Pengaruh Motivasi Kerja Terhadap Kinerja Pegawai Bagian} Kesejahteraan Rakyat Sekeretariat Daerah Kabupaten Karawang.

Hasil penelitian membuktikan bahwa pengaruh Motivasi Kerja terhadap Kinerja Pegawai pada Bagian Kesejahteraan Rakyat Sekeretariat Daerah Kabupaten Karawang positif dan signifikan. Fakta ini mengisyaratkan bahwa apabila faktor Motivasi Kerja ini ditingkatkan atau meningkat, maka peningkatan ini akan dibarengi dengan peningkatan Kinerja Pegawai pada Bagian Kesejahteraan Rakyat Sekeretariat Daerah Kabupaten Karawang, demikian halnya sebaliknya apabila faktor Motivasi Kerja ini diturunkan atau menurun, maka penurunan ini akan dibarengi dengan penurunan Kinerja Pegawai pada Bagian Kesejahteraan Rakyat Sekeretariat Daerah Kabupaten Karawang.

3. Pengaruh Kualitas Sumber Daya Manusia Dan Motivasi Kerja secara bersama-sama Terhadap Kinerja Pegawai Bagian Kesejahteraan Rakyat Sekeretariat Daerah Kabupaten Karawang.

Hasil penelitian membuktikan bahwa pengaruh Kualitas Sumber Daya Manusia dan Motivasi Kerja secara bersama-sama terhadap Kinerja Pegawai Bagian Kesra Setda Kabupaten Karawang signifikan. Fakta ini mengisyaratkan bahwa apabila faktor Kualitas Sumber Daya Manusia dan Motivasi Kerja ini ditingkatkan atau meningkat, maka peningkatan ini akan dibarengi dengan peningkatan Kinerja Pegawai Bagian Kesra Setda Kabupaten Karawang, demikian 
halnya sebaliknya apabila faktor Kualitas Sumber Daya Manusia dan Motivasi Kerja ini diturunkan atau menurun, maka penurunan ini akan dibarengi dengan penurunan Kinerja Bagian Kesra Setda Kabupaten Karawang.

\section{Pengaruh Kinerja Pegawai Tehadap Efektifitas OrganisasiBagian} Kesejahteraan Rakyat Sekeretariat Daerah Kabupaten Karawang.

Hasil penelitian membuktikan bahwa pengaruh Kinerja pegawai terhadap Efektifitas organisasi Bagian Kesra Setda Kabupaten Karawang signifikan. Fakta ini mengisyaratkan bahwa apabila faktor Kinerja pegawai ini ditingkatkan atau meningkat, maka peningkatan ini akan dibarengi dengan peningkatan Efektifitas organisasi Bagian Kesra Setda Kabupaten Karawang, demikian halnya sebaliknya apabila faktor kinerja pegawai ini diturunkan atau menurun, maka penurunan ini akan dibarengi dengan penurunan Efektifitas organisasi Bagian Kesejahteraan Rakyat Sekeretariat Daerah Kabupaten Karawang. 